\title{
CHRONIC INFLAMMATORY DEMYELINATING POLYRADICULONEUROPATHY
}

\section{Two cases with cervical spinal cord compression}

\author{
Marcos R.G. de Freitas ${ }^{1}$, Osvaldo J.M. Nascimento ${ }^{1}$, Cristiane N. Soares ${ }^{2}$, \\ Adriana Rocha Brito², Romeu Cortes Domingues ${ }^{3}$
}

\begin{abstract}
Chronic inflammatory demyelinating polyradiculoneuropathy (CIDP) is a peripheral nerve disorder probably due to an immunological disturb. It evolves either in a steadily progressive or in a relapsing and fluctuating course. Weakness is mainly in the lower limbs proximally and distally. The electro m y ography is demyelinating. The cerebral spinal fluid protein is most of times elevated. Sometimes enlarged nerves are found. There are few cases described with spinal cord compression due to hypertrophic spinal neve roots. Two patients (females, 66 and 67 years old) with diagnosis of a long standing CIDP are described. In the first one, the evolution was characterized by remission and relapsing course. The second patient had a chronic and progressive course. These patients presented after a long evolution a cervical spinal cord compression syndrome due to hypert rophic cervical roots. Neurologists must be aware of the possibility of development of spinal cord compression by enlarged spinal roots in patients with a long standing CIDP.

KEY WORDS: chronic inflammatory demyelinating polyradiculoneuropathy (CIDP), spinal root hypert rophy, spinal cord compression.
\end{abstract}

\section{Polirradiculoneuropatia desmielinizante inflamatória crônica: dois casos com síndrome de com- pressão medular}

RESUMO - A polirradiculone urqatia desmielinizante inflamatória crônica (PDIC) é uma afecção dos nervos periféricos de natureza autoimune, com evolução por surtos de exacerbação e remissão ou de evolver prog ressivo. $\mathrm{O}$ acometimento motor é predominante, com fraqueza proximal e distal nos membros inferiores. A eletroneuromiografia é do tipo desmielinizante com bloqueio de condução nervosa em dois ou mais nervos. Há aumento de proteínas do líquor. Com a evolução da doença pode haver espessamento dos nervos distal e/ou proximalmente. Excepcionalmente ocorre compressão da medula espinhal em qualquer segmento por raízes próximas hipert rofiadas. Foram estudadas duas mulheres de 66 e 67 anosrespectivamente com quadro de PDIC de longa evolução. A primeira tinha evolução por surtos e na segunda o evolver era prog ressivo. Nos dois casos o espessamento proximal dos nervos provocou síndrome de compressão medular alta. Esta complicação deve ser pensada em casos de PDIC de longa duração.

PALAVRAS-CHAVE: polineuropatia inflamatória desmielinizante crônica (PIDC), hipertrofia de raízes nervosas, compressão medular.

Ch ronic inflammatory demyelinating polyradiculoneuropathy (CIDP) usually presents as a more or less symmetric sensorimotor polyradiculoneuropathy with chronic relapsing or remitting or progressive course. There is no clear estimate of its frequency but it may re present as many as $10 \%-30 \%$ of previously undiagnosed cases of polyneuropathy'. Usually there is predominance of weakness with diffuse hyporeflexia or areflexia. The cere- b rospinal fluid (CSF) demonstrates albuminouscytologic dissociation and nerve conduction studies reveals multifocal conduction slowing, conduction block and temporal dispersion. The nerve biopsy shows primary segmental demyelination and axonal degeneration with or without inflammatory infiltration and onion bulbs ${ }^{2,3}$. The therapeutic may be considered a confirm a t o ry diagnostic criterion and consists of immune modulating agents includ-

Neuromuscular Disease Unit, Department of Neurology, Hospital Universitário Antonio Pedro da Universidade Federal Fluminense,

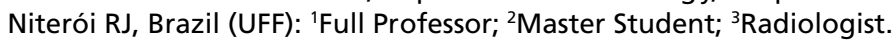

Received 4 November 2004, received in final form 2 February 2005. Accepted 1 April 2005.

Dr. Marcos R.G. de Freitas - Rua Gastão Ruch 16 / 1402 - 24220-100 Niterói RJ - Brasil. E-mail: mgdefreitas@hotmail.com 
ing corticosteroids, plasma exchange and intravenous immune globulin 4 . Occasionally the repetitive demyelination and remyelination with onion bulb formation results in gross enlargement of spinal nerves end roots. CIDP is one of the main causes of the hypert rophic neuropathy ${ }^{5}$. Thickened peripheral nerves were seen in $11 \%$ in one large series $^{3}$. Although exceedingly rare, there have been recorded cases of CIDP presenting with spinal cord compression due hypertrophic spinal roots ${ }^{5-13}$.

We report two patients with CIDP of long evolution with cervical spinal compression due to hypertrophic roots.

\section{CASES}

Case 1 - A 66-year-old black woman had recurrent $p$ a resthesias and weakness in hands and feet was first seen in 1986. At that time she had distal tetraparesis with abnormal gait, reduced tendon reflexes, proprioceptive ataxia and superficial hypoesthesia in her legs. The peripheral nerves were not thickened. Tonus, coordination and cranial nerves were normal. An electrodiagnostic evaluation showed a sensorimotor demyelinating polyneuropathy features: absence of sensitive responses, prolonged distal motor latencies and conduction block in bilateral median and ulnar nerves, severe slowing of motor conduction velocity and abolished F waves. Needle electromyography (EMG) showed active denervation in distal limbs. CSF examination revealed albuminous-cytologic dissociation and a sural biopsy showed demyelination and remyelination features, axonal regeneration and presence of some onion bulbs. The rewas no duplication in the PMP22 gene. The patient was treated successfully with prednisone; however, there were subsequent relapsing courses. Over a period of 11 years she had been maintained in alternating treatment with steroids and plasma exchange. In 2002 her symptoms worsened. She became tetraparetic and couldnot walk. The tonus was increased in lower limbs and a sensitive cervical level to painful-touch sensation could be found. The tendon reflexes were abolished and there were withdraw reflexes with bilateral Babinski sign. A cervical magnetic resonance image (MRI) revealed hypert rophy of cervical spinal roots, with spinal compression, enhanced with gadolinium (Fig 1). Steroids, imunoglobulin and plasma exchange were given with no improvement.

Case 2 - A 67-year-old woman presented in 1981 a cervical pain irradiating to the left arm. She was submitted to a myelography and a cervical spine surgery showed hypert rophic cervical roots. In 1983 she had a low back pain radiating to posterior surface of right thigh and weakness of this limb. A laminectomy was performed with some relief of the pain. There is no reference of the neurological examination in this period. Five years after she complained of pain and asymmetric weakness of all limbs, and stopped walking. No similar cases in the family are re ported. There were distal amyotrophy in all 4 limbs with slight deformity of the left hand, distal and proximal tetraparesis more severe in the lower limbs. Deep tendon reflexes were absent in lower limbs. There were superficial hypoesthesia below the knees and loss of vibratory sense in lower limbs and in the inner aspects of the left fore arm and hand. The ulnar and posterior auricular nerves were uniformly palpable and thick. The CSF showed $1 \mathrm{cell} / \mathrm{mm}^{3}$ and $48 \mathrm{mg} / \mathrm{dl}$ of protein. The tonus was increased in the lower limbs. There was bilateral Babinski sign. The left biceps reflex was present and the other tendon reflexes were absent. A nerve conduction study revealed a generalized slowing of motor conduction and a conduction block in ulnar and median nerves, the sensory nerve action potentials were abolished in the sural, ulnar and median nerves and the $\mathrm{F}$ waves were prolonged in most nerves. The EMG was not performed. Sural nerve biopsy demonstrated a great loss of fibers, some inflam-

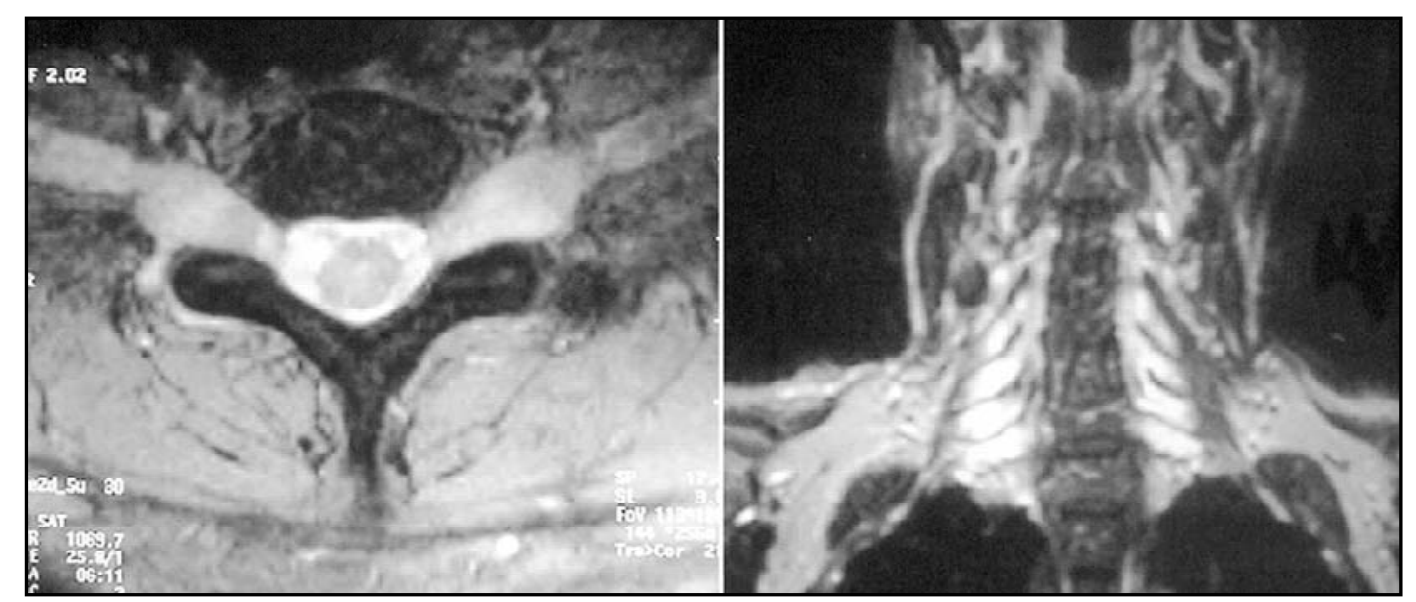

Fig 1. Case 1. Axial and coronal T2 weighted cervical spinal MRI showing roots hypertrophy. 


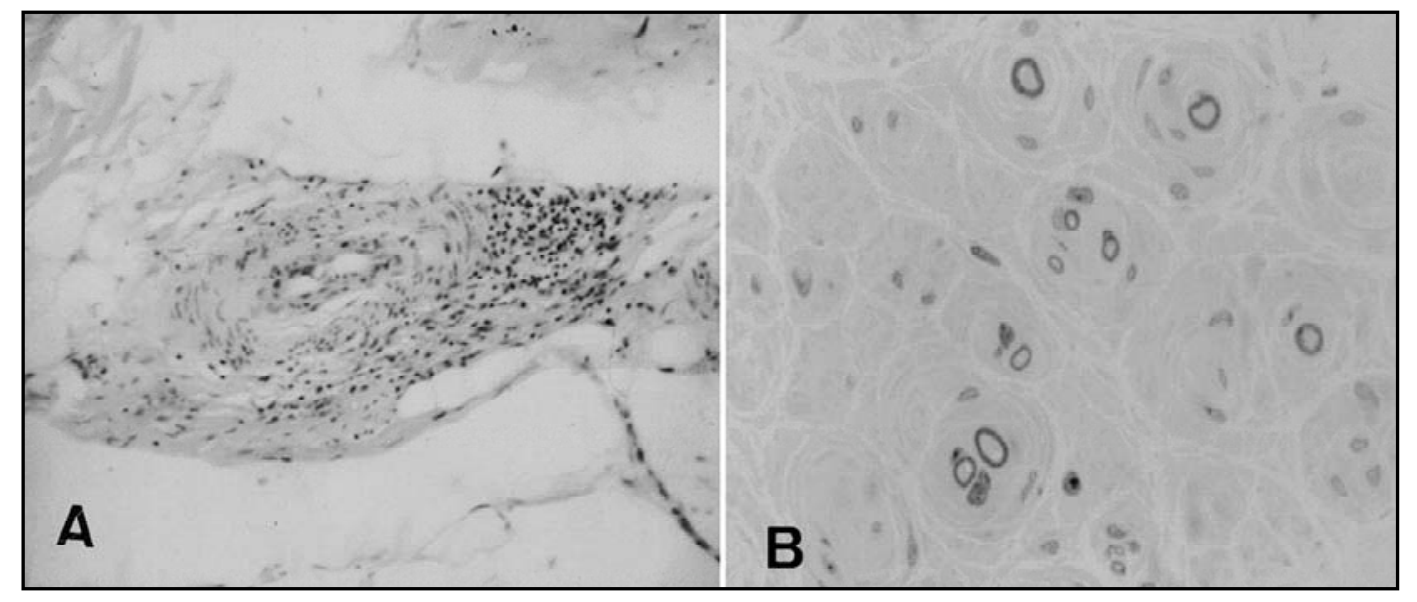

Fig 2. Case 2. Sural nerve biopsy. A) Presence of perivascular inflammatory infiltration (hematoxylin-eosin stain, X400). B) Semi-thin sections showing onion bulbs (toluidine blue stain, X400).

matory infiltrates, fibrosis, clusters of regenerated axons as well as thinly myelinated axons and many onion bulbs (Fig 2). Ultrathin sections showed similar features. The patient was put on $60 \mathrm{mg}$ prednisone per day, and 30 days after she could walk without support with gre at improvement of the strength and sensation. She had been maintained with prednisone and intravenous metilp rednisolone for 10 years. In 1999 there was worsening of her neurological examination, showing paraplegia with increased muscle tonus, bilateral Babinski sign and diminished superficial and hypoesthesia below C6 level. She died in 1999 of septicemia. A necropsy examination of the spinal cord revealed fusiform swellings of all ventral and dorsal roots. Histological examination showed that the root enlargements were due to hypert rophic demyelinating neuropathies with onion-bulb form ations and cellular infiltration.

\section{DISCUSSION}

Our two cases fulfilled clinical, neurophysiological and pathological criteria for CIDP diagnosis ${ }^{1-3}$. There was no family history of Charcot-MarieTooth (CMT) disease, and the genetic markers for CMT1A in the first patient was absent. Sural nerve biopsies performed in both patients showed images of demyelination and remyelination with onion-bulb formations. In the second patient there was also inflammatory infiltration. There was a historyof almost 17 years of relapsing and remitting courses in both patients. Treatment over several years with corticosteroids resulted in an unequivocal improvement. The patients presented many years after the onset, cervical spinal cord comp ression with tetraparalysis, hypertonicity, bilateral Babinski sign and a sensitive level. Our patient number 2 presented with radicular signs since the beginning of the disease, first in cervical level and two years after in lumbar level. The most striking feature was the diffuse, marked enlargement of peripheral roots, demonstrated in one case by MRI and the other by necropsy studies. They had an unusual clinical picture of cervical spinal cord compression determined by CIDP.

Spine MRI is a valuable addition to the diagnostic armamentarium in CIDP. Enlarged spinal roots may be identified in patients being investigated for demyelinating neuropathy as in our first case. Nerve root enhancement with gadolinium, seen in our patient, is sometimes found in inflammatory demyelinating neuropathies ${ }^{5,9,11}$.

When CIDP evolves slowly and its progression is more insidious it may be difficult to distinguish it from a hypertrophic CMT. There are few cases of here dit a ry hypert rophic neuropathy producing spinal cord compression syndromes ${ }^{14,15}$.The information described by Symmons and Blackwwod in the first case reported ${ }^{15}$ does not allow confident determination of whether the neuropathy was acquired or genetically determined. In our first case the molecular genetic studies disclosed no duplication at 17p11.2. Although we had not done DNA studies in our second patient, the relapsing and fluctuating course and the inflammatory infiltrates in the nerve biopsy confirm the diagnosis of CIDP. The nerve enhancement with gadolinium seen in patient one, although nonspecific, probably distinguish clinically active CIDP from genetically determined hypert rophic neuropathy, where the roots do not enhance ${ }^{5,9,11,16}$. Both our patients had improved in the course of the disease with corticosteroids. 
The differential diagnosis of hypert rophy roots should be done also with neurofibromatosis that could be associated with spinal compression syndromes ${ }^{13}$. The long course of disease (16 years in case 1 and 17 years in case 2) was an evident determinant for the evolution of hypertrophy, causing spinal compression. Recently it has been report$\mathrm{ed}^{17}$ the beneficial effect of interferon $\beta 1 a$ in patients with CIDP that are refractory to the conventional treatment, although controlled and randomized studies are needed to confirm the effectiveness of this treatment. Although decompressive laminectomy was not done in our patients, we a g ree that it is an acceptable option of treatment in cases with spinal cord compression ${ }^{4,5}$.

Although CIDP is a common disorder of the peripheral nerve system, the radicular and the spinal compression due to this syndrome is seldom related $^{5-13}$. In case of patients with CIDP with enlarge d $n$ e rves and minimal symptoms and signs of spinal cord involvement it is necessary to perform MRI studies of the spine and try to modify the treatment to prevent the functional deterioration. Our cases and other observations already mentioned suggest that new forms of treatment are needed in cases of spinal cord compression due do enlarged spinal roots in CIDP.

\section{REFERENCES}

1. Kissel JT, Mendell JR. Chronic inflammatory demyelinating polyradiculoneuropathy. In Kissel JT, Mendell JR, Cornblath DR (Eds). Diagnosis and management of peripheral nerves. New York: Oxford Univ Press, 2001:173-191.

2. Dyck PJ, Lais AC, Ohta M, et al. Chronic inflammatory polyradiculoneuropathy. Mayo Clin Proc 1975;50:621-637.
3. Barohn RJ, Kissel JT, Warmolts JR, Mendell JR. Chronic inflammatory demyelinating polyradiculoneuropathy: clinical characteristics, course and recommendations for diagnostic criteria. Arch Neurol 1989;46: 878-884.

4. Midroni G, Dyck PJ. Chronic inflammatory demyelinting polyradiculoneuropathy: unusual clinical features and terapeutic responses. Neurology 1996;46:1206-1212.

5. Schady W, Goulding PJ, Lecky BRF, King RHM, Smith CML. Massive nerve root enlargement in chronic inflammatory demyelinating polyneuropathy. J Neurol Neurosurg Psychiatry 1996; 61:636-640.

6. Aïdi M El Aloui Faris, Amarti A, Belaïdi H, et al. Polyradiculoneuropathie inflammatoire démyélinisante chronique hypertrophique avec atteinte des nerfs crâniens: à propos de deux observations. Rev Neurol (Paris) 2002;158:819-823.

7. De Silva RN, Willison HJ, Doyle D, Weir AI, Hadley, Thomas AM. Nerve root hypertrophy on chronic inflammatory demyelinating polyneuropathy. Muscle Nerve 1994;17:168-170.

8. Duarte J, Cruz Martinez A, Rodriguez F, Mendoza A, Sempere AP, Claveria LE. Hypertrophy of multiple cranial nerves and spinal roots in chronic inflammatory demyelinating neuropathy. J Neurol Neurosurg Psychiatry 1999;67:685-687.

9. Duggins AJ, McLeod JG, Pollard JD et al. Spinal root and plexus hypertrophy in chronic inflammatory demyelinating polyneuropathy. Brain 1999;122:1383-1390.

10. Ginsberg L, Platts AD, Thomas PK. Chronic inflammatory demyelinating polyneuropathy mimicking a lumbar spinal stenosis syndrome. J Neurol Neurosurg Psychiatry 1995;59:189-191.

11. Mizuno K, Nagamatsu M, Hattori N, et al. Chronic inflammatory demyelinating polyradiculoneuropathy with diffuse and massive peripheral nerve hypertrophy: distinctive clinical and magnetic resonance imaging features. Muscle Nerve 1998;21:805-808.

12. Oguz B, Oguz KK, Cila A, Tan E. Diffuse spinal and intercostal nerve involvement in chronic inflammatory demyelinating polyradiculoneuropathy: MRI findings. Eur Radiol 2003:13(S4):L230-234.

13. Pytel P, Rezania K, Soliven B, Frank J, Wollmann R. Chronic inflammatory demyelinating polyradiculoneuropathy (CIDP) with hypertrophic spinal radiculopathy mimicking neurofibromatosis. Acta Neuropathol 2003; 105:185-188.

14. Rosen SA, Wang H. Cornblath DR, Uematsu S, Hurko O. Compression syndromes due to hypertrophic nerve roots in hereditary motor sensory neuropathy type I. Neurology 1989;39:1173-1177.

15. Symonds CP, Blackwood W. Spinal Cord compression in hypertrophic neuritis. Brain 1962;85:251-259.

16. Morgan GW, Barohn RJ, Bazan C III, King RB, Klucznik RP. Nerve root enhancement with MRI in inflammatory demyelinating polyradiculoneuropathy. Neurology 1993;43:618-620.

17. Villa AM, Garcea O, Egidio M, Saizar R, Sica REP. Interferon $\beta 1$ a in chronic inflammatory demyelinating polyneuropathy. A rq Neuropsiquiatr 2004;62 